\title{
Design of Microcontroller Based Fire Detector with Output Warning SMS Information and Automatic Extinguisher
}

\author{
Abdul Zain $^{1, a}$, Rudi Hartono ${ }^{2, b}$ dan Sri Handani $W^{3}$ \\ ${ }^{1,2}$ Departement of Electrical Engineering, Sekolah Tinggi Teknologi Bontang, Jl Letjen S. Parman No 65 Bontang \\ ${ }^{3}$ Departement of Informatics Engineering, Sekolah Tinggi Teknologi Bontang, Jl Letjen S. Parman No 65 Bontang \\ a jainbtg2013@gmail.com \\ b11rudi.hrt@gmail.com
}

\begin{abstract}
Conflagration is an unpredictable tragedy. It may occur whether in the woodland areas or in the residential areas. Typically, it would only be recognized if indeed the flames spread and the smoke intensified. This study aims to detect fires using the MQ-2 smoke sensor, DS18b20 temperature sensor, and fire sensor. Using Arduino Uno as the controller, this system's output is in the form of an alarm buzzer, Short Message Service (SMS) information using SIM800L, and an automatic fire pump. This system operates to detect the temperature shifts, the smoke concentration and the existence of a fire point which triggers an alarm in the form of a siren if two out of the three sensors are activated. It, then, sends information by Short Message Service (SMS) and automatically triggers the pump as the result. The fire sensor can detect hotspots with a maximum distance of $80 \mathrm{~cm}$ and the DS18b20 temperature sensor has an average reading error of $0.27^{\circ} \mathrm{C}$ with a maximum reading error of $0.5^{\circ} \mathrm{C}$. The MQ-2 smoke sensor can detect smoke where the change in smoke concentration is directly proportional to the sensor output voltage. There are three conditions to determine fire conditions, namely the temperature sensor reads more than equal to $55^{\circ} \mathrm{C}$ and the fire sensor is active, or the temperature sensor reads more than equal to $55^{\circ} \mathrm{C}$ and the smoke sensor reads more than equal to $1000 \mathrm{ppm}$, or the fire sensor is active and smoke sensor reads greater than equal to $1000 \mathrm{ppm}$.
\end{abstract}

Keywords-component; conflagration, MQ-2 smoke censor, fire censor, DS18b20 temperature censor, Sim800L, automatic extinguishing.

\section{Introduction}

Fire is an oxidation process of three elements air, fuel, and heat source [1]. Conflagration is an unpredictable tragedy [2]. This disaster can occur in the forest areas as well as in residential areas, this incident is not expected by the community because it will cause material, psychological losses and allow for casualties.
The fires in urban areas are generally caused by an electrical short circuit (short circuit) on the power cable, a leak in the LPG gas cylinder pipe, or human negligence, such as throwing cigarette butts carelessly. Apart from those caused by human factors, fire disasters can also be caused by natural factors such as lightning, earthquakes, volcanic eruptions, long droughts etc [3].

In general, the fires will only be known if the flames have enlarged and smoke has risen. These conditions will cause casualties, the detriment which are not small and the cessation of business activities or causing environmental damage [4]. When the fires occur, the community worked together to extinguish before the firefighters arrived, the real fact that, the problems were often occurred when firefighters arrive at the location are due to several factors, are delay in information, congested roads to the location, areas that are difficult to reach and the readiness of the officers [3].

To suppress the fire numbers, it is need to take an action which prioritizes safety. Warning of signs of fire is one solution to fire hazards. Signs of fire can be detected because every fire always emits smoke and heat [5]. Based on the above conditions, a fire detection device is designed with information output of an SMS gateway and automatic extinguishing.

This tool is designed for early detection of fire symptoms by using several censors such as, MQ-2 smoke censor, fire censor, DS18b20 temperature censor 
with the Arduino Uno microcontroller as a data processor. By this censor sensing, if two of the three censors detect early signs of fire, it will activate an alarm in the form of a siren and SMS will be sent to the contact which has been set as information and it will turn on the pump to spray water into the area where the fire is happening so it does not enlarge.

\section{Research Methodology}

\section{A. Research Schedule}

The research has been conducted on January 2020 to July 2020. This research activity consists of two parts; (1) design the tools and (2) test the tools. The research was conducted at the Laboratory of Electrical Engineering Program Study, Bontang Engineering College.

\section{B. Research Stages}

Steps of the research can be seen in figure 1.

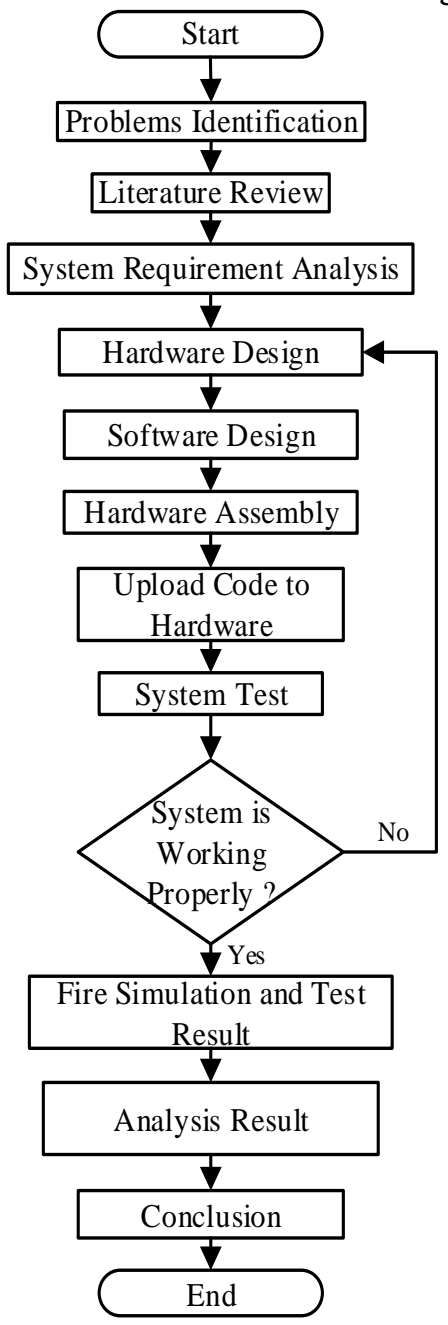

DOI : http://dx.doi.org/10.31963/intek.v7i2.2639
Figure 1. Research Flowchart

\section{System Architecture}

System architecture is a general description of the system to be designed and built. Figure 2 shows the fire detection device design model which will be built in accordance with literature review and system requirement analysis.

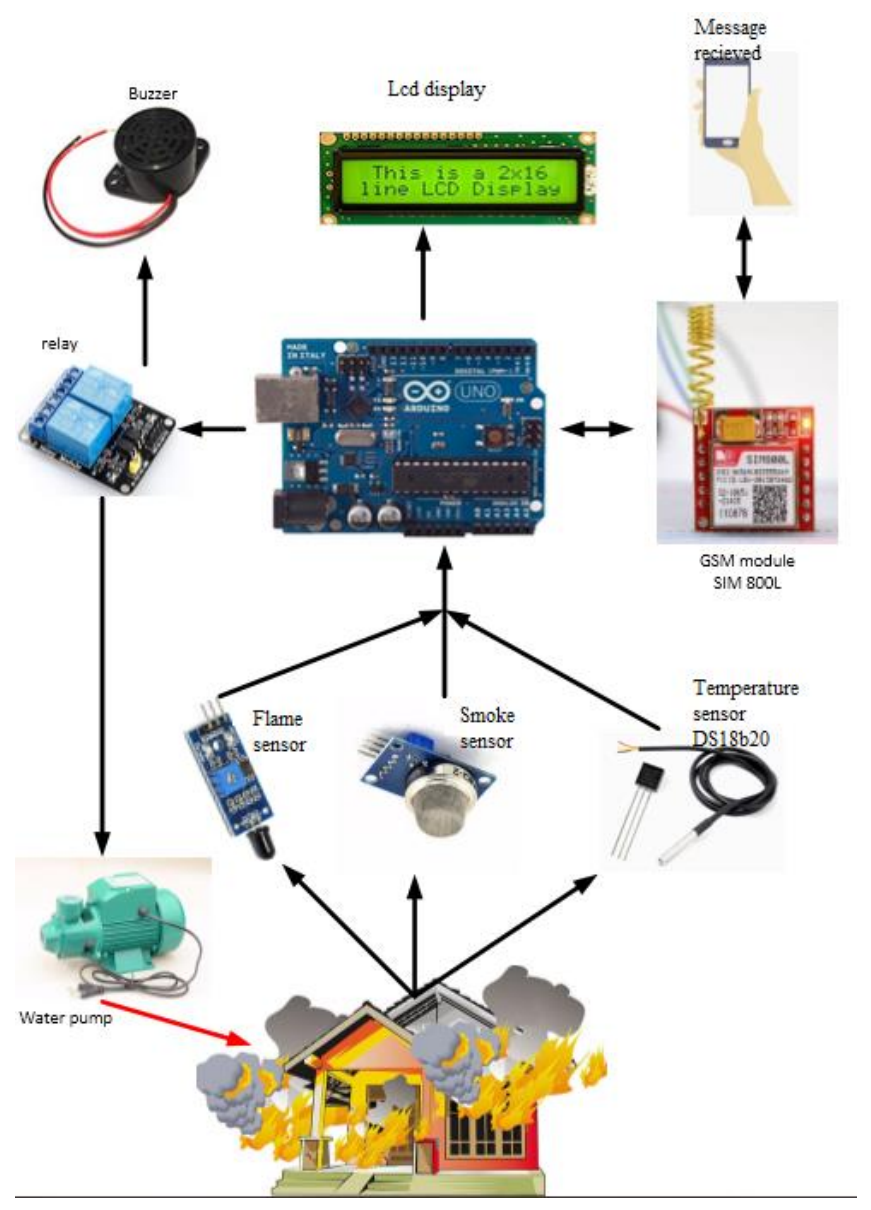

Figure 2. System Architecture

In figure 2, it can be seen that the configuration of the fire detection and automatic extinguishing devices to be built consists of input, process, and output. From the input side, this research using several censors consisting of a DS18b20 temperature censor, MQ-2 smoke censor and flame censor. Arduino Uno is used as a data processor which will receive data from censors and will be processed to determine conditions that are indicated as conflagration. The output of this system is in the form of a buzzer alarm, Sim 800L module to sent information of conflagration, the LCD is used to display censor data and automatic start of the pump. 


\section{System Design}

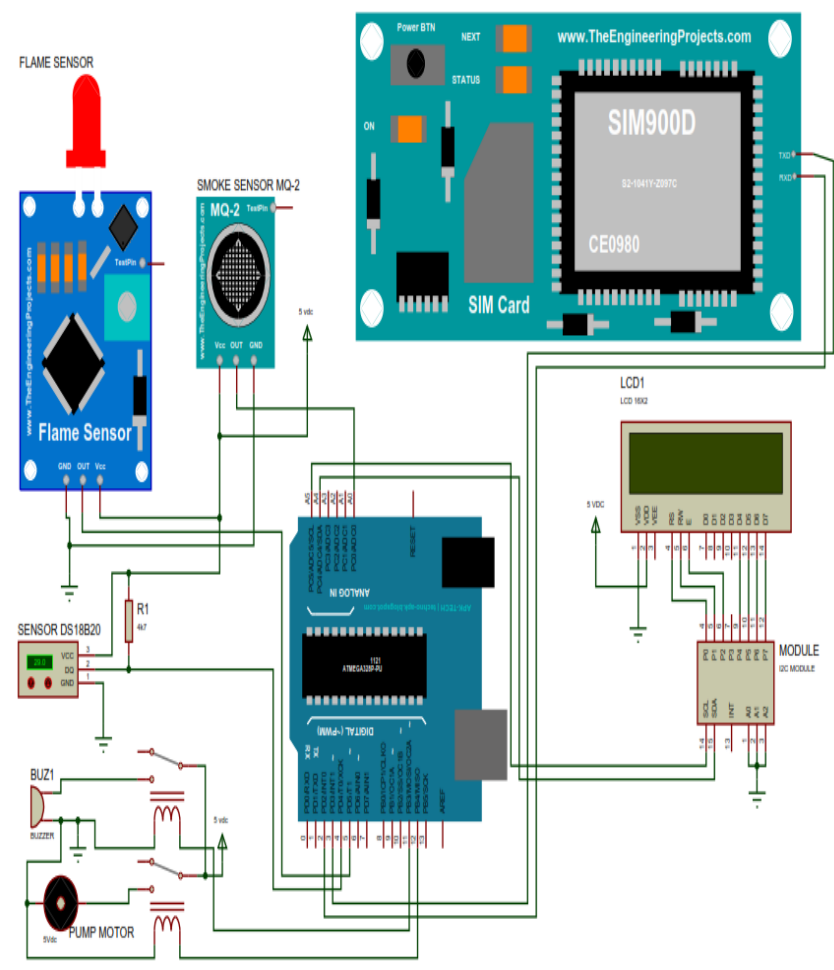

Figure 3. System Design

Figure 3 is a built system design. The Arduino Uno microcontroller pin configuration for the censors is set up as follows:

1. The Flame censor output signal is a digital, the DO censor pin is connected to pin 5 of the microcontroller.

2. The DS18b20 censor output signal is a digital, the pin Out censor is connected to pin 4 of the microcontroller.

3. The MQ-2 censor output signal is an analog, the pin A out censor is connected to pin A0 on the microcontroller.

4. The I2C module combined with LCD $16 \times 2$ to economize pin of microcontroller. on the SDA and SCL pins I2C the LCD module is connected to the $\mathrm{A} 4$ and $\mathrm{A} 5$ pins of the microcontroller.

5. The Sim $800 \mathrm{~L}$ module can be communicated with the microcontroller by using serial communication, the pin RX, TX module is connected to the pin 2 and pin 3 on the microcontroller.
6. To activate the buzzer and water pump, an automatic switch in the form of a relay is used. The signal relay pins are connected to pin 11 and pin 12 on the microcontroller.

\section{E. Flowchart System}

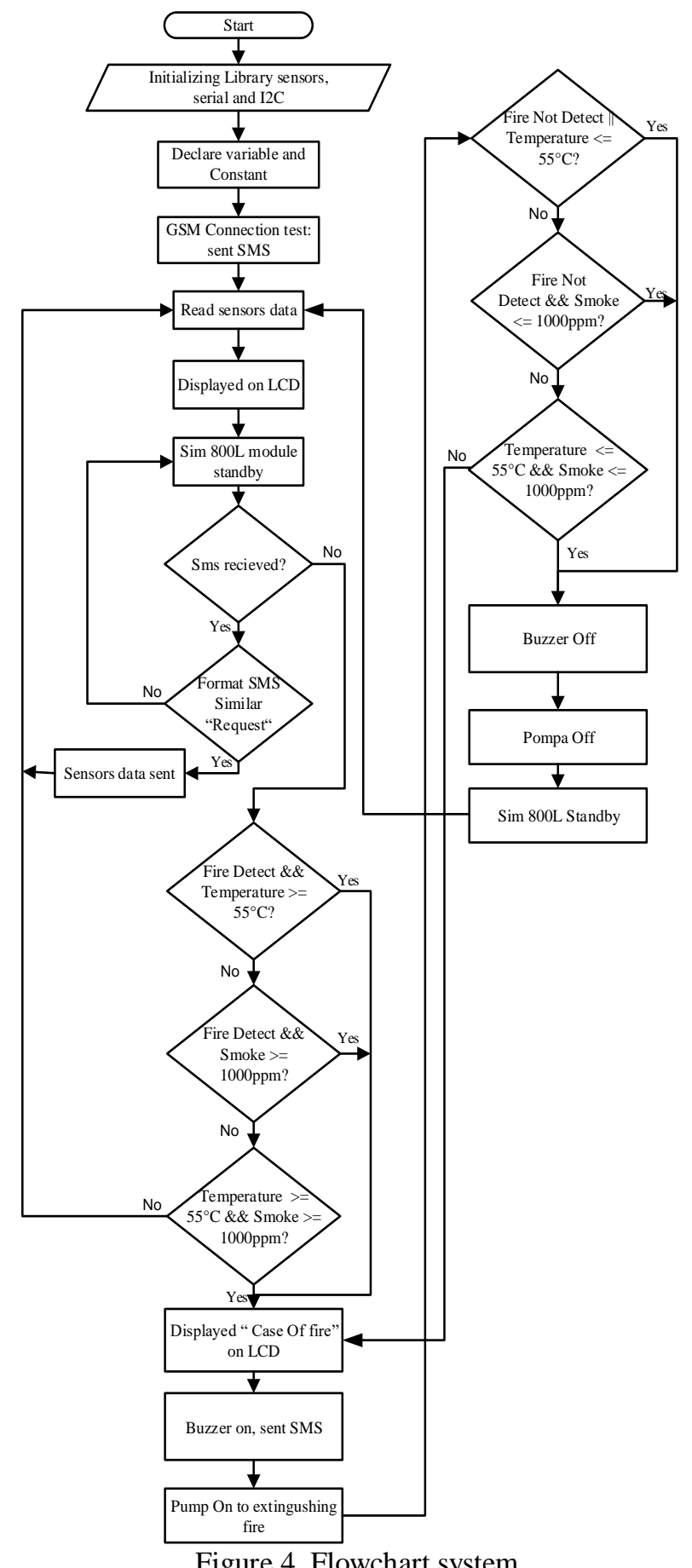

Figure 4. Flowchart system

Fire alarm system and automatic extinguisher are designed with basic capabilities based on SelfMonitoring, Analyzing \& Reporting Technology (SMART) [6]. The SMART system is a system designed 
to detect potential fires, analyze in the presence of three censors are used, if two of the three censors are active, so the microcontroller will give commands to send information to the contact number that has been previously arranged. The microcontroller will activate the pump automatically to make extinguisher. The Information is received in the form of SMS is fire warning information to call the authorities to further handle the fire. There are how to the system is built as follows:

1. Initializing library, serial communication and $\mathrm{I} 2 \mathrm{C}$ communication.

2. Declared variables.

3. Sent SMS "Test connection SMS" the first time the system is turned on.

4. Read and process the data from censors and displayed on the LCD.

5. Censor of the data can be accessed through via mobile phone by sending an SMS with the format "Request".

6. Set point of value censor to indicate the fire

a. The flame censor is LOW

b. The temperature censor is more than equal $55^{\circ} \mathrm{C}$ [5].

c. The smoke censor is more than equal $1000 \mathrm{ppm}$ [7].

7. There are three conditions are indicated as fire conditions:

a. The flame censor is LOW and the temperature censor is more than equal set point value.

b. The flame censor is LOW and the smoke censor is more than equal set point value.

c. The temperature censor and smoke censor are valued more than equal to set point value.

8. If one of the conditions above is achieved, it will activate the buzzer, it sends message fire warning information to the contact number that has been set, displays the status "case of fire" in LCD, it will activate the pump to perform a extinguisher.

9. If the censor value is less than the set point value, the system will deactivate the pump, the buzzer and LCD will display the value censor.

10.The system will return to monitoring mode.

\section{Result and Discussion}

A. Hardware Assembly

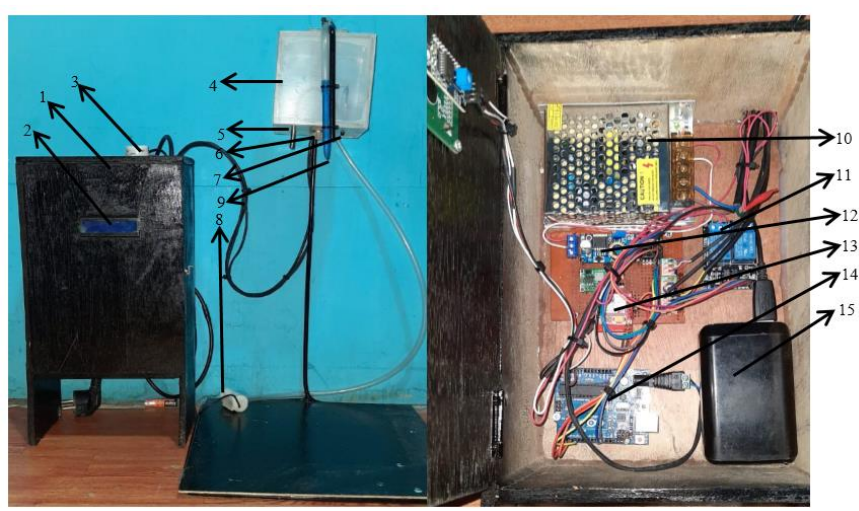

Figure 5. Hardware Assembly

The design of the fire detector above is still a prototype. Figure 5 is the result of the hardware assembly used in this research.

caption 5 as bellows :

1. Box panel

2. LCD $16 \times 2$

3. Buzzer

4. Censors box

5. Censor DS18b20

6. Censor MQ-2

7. Flame censor

8. Pump

\section{B. Sim 800L Test Result}

In this research, using by the Sim $800 \mathrm{~L}$ module as a component that functions to send SMS information to the contact number that has been set. It aims to ensure to send the SMS information which can be received to the contact number that has been set. In module of operation uses a Led indicator as a cellular network signal status. The indicators are as follows:

1. It is blinking every second it indicates that the module is running but has made connection to the cellular network yet. 
2. It is blinking every two seconds it indicates that General Package Radio Service (GPRS) data is active.

3. If it is blinking every 3 seconds indicates the module is connected to the cellular network and can send and receive calls or Short Message Service (SMS).

Table 1. AT Command Sim 800L module

\begin{tabular}{|l|l|}
\hline Syntax & Description \\
\hline AT+COPS & Operator Selection \\
\hline AT+CREG & Registrasion Network \\
\hline AT+CSQ & Signal Quality Report \\
\hline AT+CFUN & Set Phone Functionality \\
\hline AT+CMGF & Select SMS Message Format \\
\hline AT+CMGS & Send SMS Message \\
\hline AT+CMGR & Read SMS Message \\
\hline AT+CNMI & New Message Indication \\
\hline
\end{tabular}

Table 1 above is some of the commands are used to access the Sim $800 \mathrm{~L}$ by means of serial communication or has been written in the code program. The result of the test are as in figure 6.

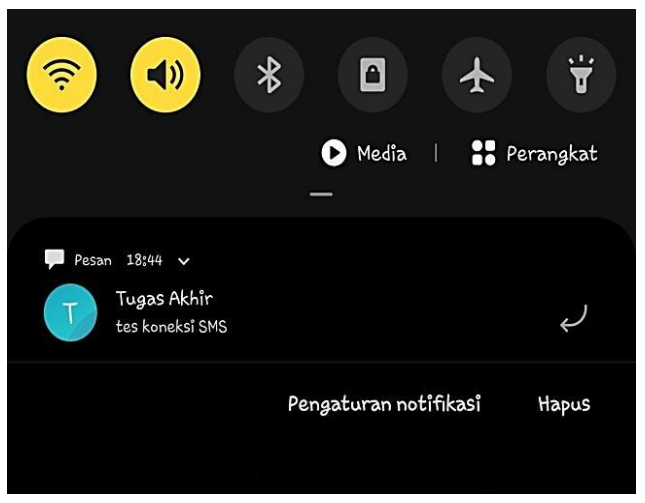

Figure 6. SMS Recieved

\section{Temperature Censor Test Result}

\section{TEMPERATURE SENSOR TEST RESULT}

$$
\text { - Thermometer }\left({ }^{\circ} \mathrm{C}\right) \quad \text { Sensor DS18b20 }\left({ }^{\circ} \mathrm{C}\right)
$$

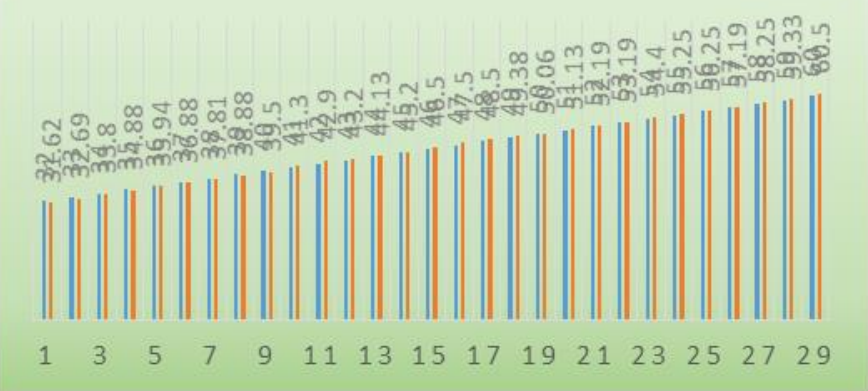

Figure 7. Temperature Censor Test Result

The results shown in figure 7 are a test of the DS18b20 temperature censor which is compared with a mercury thermometer by blowing hot air using a heat gun.

D. Flame Censor Test Result

\begin{tabular}{|c|c|c|c|}
\hline Ranges & $\begin{array}{l}\text { Flame } \\
\text { Censor }\end{array}$ & Buzzer & LCD Display \\
\hline $10 \mathrm{~cm}$ & $L O W$ & On & Fire Detected \\
\hline $20 \mathrm{~cm}$ & LOW & On & Fire Detected \\
\hline $30 \mathrm{~cm}$ & $L O W$ & On & Fire Detected \\
\hline $40 \mathrm{~cm}$ & $L O W$ & On & Fire Detected \\
\hline $50 \mathrm{~cm}$ & $L O W$ & On & Fire Detected \\
\hline $60 \mathrm{~cm}$ & $L O W$ & On & Fire Detected \\
\hline $70 \mathrm{~cm}$ & $L O W$ & On & Fire Detected \\
\hline $80 \mathrm{~cm}$ & $L O W$ & On & Fire Detected \\
\hline $90 \mathrm{~cm}$ & $H I G H$ & Off & Fire Not Detected \\
\hline $100 \mathrm{~cm}$ & $H I G H$ & Off & Fire Not Detected \\
\hline
\end{tabular}

This test is done by providing a fire point just below the flame censor and measuring the maximum distance the flame censor can detect fire. The test results are shown in table 2 .

\section{E. Gas Censor Test Result}

Table 3. Gas Censor Test Result

\begin{tabular}{|c|c|c|}
\hline Condition & Censor MQ-2 & Censor Volt \\
\hline Without Smoke & $0 \mathrm{ppm}$ & 0,16 volt \\
\hline Thin Smoke & $334 \mathrm{ppm}$ & 0,80 volt \\
\hline Medium Smoke & $2345 \mathrm{ppm}$ & 1,13 volt \\
\hline Thick Smoke & $4141 \mathrm{ppm}$ & 1,19 volt \\
\hline
\end{tabular}

The test is done by giving smoke to the smoke censor with different levels of concentration. The conditions change in smoke concentration directly proportional to 
the increase PPM value that will be displayed on the LCD. The test results are shown in table 3.

\section{F. Third Conditions Fire Detector Testing}

1. Condition 1 Test Result

Table 4. Condition 1 Test Result

\begin{tabular}{|c|c|c|c|c|c|}
\hline $\begin{array}{c}\text { Temp. } \\
\text { Censor }\end{array}$ & $\begin{array}{c}\text { Flame } \\
\text { Censo } \\
\mathrm{r}\end{array}$ & $\begin{array}{c}\text { Sim } \\
800 \mathrm{~L}\end{array}$ & Buzzer & Pump & $\begin{array}{c}\text { LCD } \\
\text { display }\end{array}$ \\
\hline $52,68^{\circ} \mathrm{C}$ & Low & $\begin{array}{c}\text { Stand } \\
\text { by }\end{array}$ & Off & Off & $\begin{array}{c}\text { Censors } \\
\text { data }\end{array}$ \\
\hline $57,19^{\circ} \mathrm{C}$ & High & $\begin{array}{c}\text { Stand } \\
\text { by }\end{array}$ & Off & Off & $\begin{array}{c}\text { Censors } \\
\text { data }\end{array}$ \\
\hline $55,18^{\circ} \mathrm{C}$ & Low & $\begin{array}{c}\text { Sent } \\
\text { SMS }\end{array}$ & On & On & Case of Fire \\
\hline $56,38^{\circ} \mathrm{C}$ & Low & $\begin{array}{c}\text { Sent } \\
\text { SMS }\end{array}$ & On & On & Case of Fire \\
\hline $57,20^{\circ} \mathrm{C}$ & Low & $\begin{array}{c}\text { SMS } \\
\text { sent }\end{array}$ & On & On & Case of Fire \\
\hline $61,28^{\circ} \mathrm{C}$ & Low & $\begin{array}{c}\text { SMS } \\
\text { sent }\end{array}$ & On & On & Case of Fire \\
\hline
\end{tabular}

2. Condition 2 Test Result

Table 5. Condition 2 Test Result

\begin{tabular}{|c|c|c|c|c|c|}
\hline $\begin{array}{c}\text { Flame } \\
\text { Censor }\end{array}$ & $\begin{array}{c}\text { Smoke } \\
\text { Censor }\end{array}$ & $\begin{array}{c}\text { Sim } \\
800 \mathrm{~L}\end{array}$ & Buzzer & Pump & $\begin{array}{c}\text { LCD } \\
\text { display }\end{array}$ \\
\hline High & $0 \mathrm{ppm}$ & $\begin{array}{c}\text { Stand } \\
\text { by }\end{array}$ & Off & Off & $\begin{array}{c}\text { Censors } \\
\text { data }\end{array}$ \\
\hline Low & $\begin{array}{c}441 \\
\mathrm{ppm}\end{array}$ & $\begin{array}{c}\text { Stand } \\
\text { by }\end{array}$ & Off & Off & $\begin{array}{c}\text { Censors } \\
\text { data }\end{array}$ \\
\hline High & $\begin{array}{c}1338 \\
\mathrm{ppm}\end{array}$ & $\begin{array}{c}\text { Stand } \\
\text { by }\end{array}$ & Off & Off & $\begin{array}{c}\text { Censors } \\
\text { data }\end{array}$ \\
\hline Low & $\begin{array}{c}2125 \\
\mathrm{ppm}\end{array}$ & $\begin{array}{c}\text { SMS } \\
\text { sent }\end{array}$ & On & On & Case of Fire \\
\hline Low & $\begin{array}{c}2133 \\
\mathrm{ppm}\end{array}$ & $\begin{array}{c}\text { SMS } \\
\text { sent }\end{array}$ & On & On & Case of Fire \\
\hline Low & $\begin{array}{c}1153 \\
\mathrm{ppm}\end{array}$ & $\begin{array}{c}\text { SMS } \\
\text { sent }\end{array}$ & On & On & Case of Fire \\
\hline
\end{tabular}

3. Condition 3 Test Result

Table 6. Condition 3 Test Result

\begin{tabular}{|c|c|c|c|c|c|}
\hline $\begin{array}{c}\text { Temp. } \\
\text { Censor }\end{array}$ & $\begin{array}{c}\text { Smoke } \\
\text { Censor }\end{array}$ & $\begin{array}{c}\text { Sim } \\
800 \mathrm{~L}\end{array}$ & Buzzer & Pump & $\begin{array}{c}\text { LCD } \\
\text { display }\end{array}$ \\
\hline $30,81 \mathrm{C}$ & $0 \mathrm{ppm}$ & $\begin{array}{c}\text { Stand } \\
\text { by }\end{array}$ & Off & Off & $\begin{array}{c}\text { Censors } \\
\text { data }\end{array}$ \\
\hline $\begin{array}{c}59,20^{\circ} \\
\mathrm{C}\end{array}$ & $\begin{array}{c}300 \\
\mathrm{ppm}\end{array}$ & $\begin{array}{c}\text { Stand } \\
\text { by }\end{array}$ & Off & Off & $\begin{array}{c}\text { Censors } \\
\text { data }\end{array}$ \\
\hline $\begin{array}{c}47,69^{\circ} \\
\mathrm{C}\end{array}$ & $\begin{array}{c}1720 \\
\mathrm{ppm}\end{array}$ & $\begin{array}{c}\text { Stand } \\
\text { by }\end{array}$ & Off & Off & $\begin{array}{c}\text { Censors } \\
\text { data }\end{array}$ \\
\hline $\begin{array}{c}57,50^{\circ} \\
\mathrm{C}\end{array}$ & $\begin{array}{c}1574 \\
\mathrm{ppm}\end{array}$ & $\begin{array}{c}\text { SMS } \\
\text { sent }\end{array}$ & On & On & Case of Fire \\
\hline $\begin{array}{c}60,15^{\circ} \\
\mathrm{C}\end{array}$ & $\begin{array}{c}3140 \\
\mathrm{ppm}\end{array}$ & $\begin{array}{c}\text { SMS } \\
\text { sent }\end{array}$ & On & On & Case of Fire \\
\hline
\end{tabular}

\section{G. Discussion}

From the test results of table 4 to table 6 above, it can be concluded that when two of the three censors detect more than the same set point value, it will indicate a fire DOI : http://dx.doi.org/10.31963/intek.v7i2.2639 and the system will activate the buzzer, send an SMS and activate the pump, the received SMS information is as in figure 8. But if one of the two censors is less than the set point value, the system will return to monitoring mode

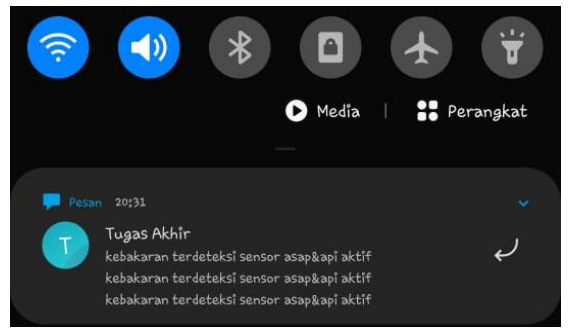

Figure 8. SMS Recieved

\section{Conclusion}

Based on the design and testing of fire detector with output warning information and automatic extinguisher which have been carried out and the problems which have arisen, there are some conclusions can be drawn, including:

1. It has been designed successfully and made a fire detector with warning information and automatic extinguisher using the DS18b20 temperature censor, MQ-2 smoke censor, fire censor, sim 800L module, buzzer, pump, and relays based on Arduino Uno microcontroller can work according to the design and program made.

2. The flame censor can detect hotspots or fire with a maximum distance of $80 \mathrm{~cm}$ and the DS18b20 temperature censor has a maximum reading error of $+/-0,5^{\circ} \mathrm{C}$.

3. The MQ-2 smoke censor can detect smoke where the change in smoke concentration is directly proportional to the censor output voltage.

4. There are three conditions for determining fire conditions, are temperature censor reads greater than equal to $55^{\circ} \mathrm{C}$ and active fire censor, or temperature censor reads greater than equal to $55^{\circ} \mathrm{C}$ smoke censor reads greater than equal to $1000 \mathrm{ppm}$, or active fire censor and smoke censor reads more than equal to $1000 \mathrm{ppm}$.

5. The output of this system is a buzzer alarm, SMS information with the sim800L module and automatic shutdown can work as expected and it can help fight fires 


\section{Acknowledgement}

The authors would like to thank to Head of Electrical Engineering Study Program, STITEK Bontang, Head of Electrical Engineering Laboratory, STITEK Bontang, Lecturers and Staff of STITEK Bontang who have made positive contributions to the completion of this research.

\section{References}

[1] Fatmawati, Ratri. "Audit Keselamatan Kebakaran Di Gedung PT. X Jakarta Tahun 2009" (Fire Safety Audit at PT. X Jakarta Year 2009). Skripsi. Fakultas Kesehatan Masyarakat, Kekhususan Keselamatan dan Kesehatan Kerja, Universitas Indonesia, Depok. 2009.

[2] Sutikno, Tole, Wahyu Sapto Aji, dan Rahmat Susilo. "Perancangan Alat Pendeteksi Kebakaran Berdasarkan Suhu dan Asap Berbasis Mikrokontroller AT89S52" (Design of a fire detection device based on temperature and smoke based on the AT89S52 microcontroller). TELKOMNIKA, 4(1), pp. 49-56. 2006.

[3] Yendri, Dodon, Wildian, dan Amalia Tiffany. "Perancangan Sistem Pendeteksi Kebakaran Penduduk Pada Daerah Perkotaan Berbasis Mikrokontroller" (Microcontroller-Based Design of Resident Fire Detection Systems in Urban Areas). Seminar
Nasional Sains dan Teknologi. Jakarta, Indonesia: Fakultas Teknik Universitas Muhammadiyah Jakarta. 2017.

[4] Sipayung, Lawmen Miane, "Rancangan Sistem Deteksi Kebakaran dan Pemadaman Otomatis Berbasis Mikrokontroller Atmega8535" (The Design of Fire Detection and Automatic Extinguishing Systems Based on the Atmega8535 Microcontroller) .Skripsi. Fakultas Ilmu Matematika dan Ilmu Pengetahuan Alam, Universitas Sumatera Utara, Medan. 2017.

[5] Zain, Abdul. "Rancang Bangun Sistem Proteksi Kebakaran Menggunakan Smoke dan Heat Detector"(Fire Protection System Design using Smoke and Heat Detector). Journal INTEK. 3(1), pp.36-42. 2016.

[6] Apryandi, Subhan. "Rancang Bangun Sistem Detektor Kebakaran Via Handphone Berbasis Mikrokontroller". (Microcontroller Based Mobile Fire Detector System Design), Jurnal Untan. Vol (1) no.1, 2013.

[7] Nurrochim, Faisol. "Simulasi Alat Pendeteksi Kebakaran Menggunakan Censor Asap MQ-2, Censor Suhu LM35, dan Module Wifi ESP8266 Berbasis Mikrokontroller Arduino" (Simulation of a fire detection tool using the MQ-2 smoke censor, LM35 temperature censor, and the ESP8266 WiFi module based on the Arduino microcontroller). Undergraduate thesis, Repository UnmuhJember. 2017. 